\title{
MENJAGA VOLATILITAS NILAI TUKAR: FAKTOR PENDUKUNG PENGEMBANGAN BISNIS DI ASEAN¹
}

\author{
A. Ika Rahutami \\ Fakultas Ekonomi Unika Soegijapranata Semarang
}

\begin{abstract}
Currently, economic globalization brings a big impact for business environment in Indonesia. The competition capability is one of requirement to access a broader market. Instead of the manufacture's competence itself, a conducive macroeconomic condition will support the global competition. If the target of business is a wider market, the stability of currency should be a sustain factor. One of the currency's risks is exchange rate volatility. The bigger volatility, the bigger risk and unstable condition hence will impede intervention to foreign market.

Nowadays ASEAN establish the new integration process after the AFTA trading agreement is not sufficient to construct market and generate a better welfare. AFTA is created for a better and extensive economic integration in 2020 namely ASEAN Economic Community (AEC). Based on more stable economic integration, European Union, it can be concluded that a monetary agreement, moreover the common currency will create more stable economic condition and exchange rate. A heterogeneous economic system, per capita income, economic level, currency and exchange rate among ASEAN countries being a problem for adjustment. This study observes the exchange rate volatility in ASEAN countries. The results of this study showed that the based on the financial integration framework indicator, ASEAN countries require a lot of adjustment that will make a more convergence economic policy to construct financial integration framework
\end{abstract}

Keywords : Globalization, AEC, currency votality, bussines development

\section{PENDAHULUAN}

Globalisasi ekonomi menyebabkan aliran barang, jasa dan modal di dunia dapat bergerak dengan bebas. Perdagangan bebas memberikan setidaknya tiga manfaat bagi masyarakat. Pertama, sistem perdagangan bebas yang diiringi dengan persaingan bebas akan menghindarkan berkembangnya kondisi X-inefficiency. Kompetisiakan mendorong produsen untuk melaksanakan proses produksi yang efisien sehingga harga yang dibebankan kepada konsumen menjadi relatif murah. Kedua, sistem perdagangan internasional yang bebas akan meminimumkan ketidakstabilan ekonomi makro yang menjurus pada "stop-go macroeconomics cycles", sedangkan kebijakan proteksi yang disertai dengan adanya kurs mata uang yang tidak realistis cenderung mengakibatkan terjadinya "foreign exchange bottleknecks." Ketiga, liberalisasi perdagangan internasional akan mendorong berlangsungnya proses produksi dalam skala penuh dengan memperluas produksi untuk ekspor dan menimbulkan situasi produksi yang "increasing return to scale," sehingga dapat berkompetisi di pasar internasional.

Liberalisasi perdagangan memicu terjadinya kerjasama ekonomi antar negara, baik itu bersifat regional, bilateral maupun multilateral. Regionalisme maupun penciptaan integrasi ekonomi lainnya semakin hari semakin menarik karena dipandang akan memberikan lebih banyak keuntungan dibandingkan dengan biaya yang ditimbulkan. Dalam pemahaman populer, regionalisme ekonomi merupakan suatu tindakan yang dilakukan oleh

1 Telah dipresentasikan dalam The $1^{\text {st }}$ National Conference - Faculty of Economics Widya Mandala Catholic University Surabaya, 4 September 2007 
sekelompok perekonomian yang berdekatan secara geografis untuk mencapai integrasi ekonomi kawasan. Integrasi ekonomi secara regional menjadi tidak hanya bermanfaat bagi suatu negara namun juga bagi dunia bisnis. Hal ini disebabkan karena dunia bisnis sedang menghadapi lingkungan persaingan yang cenderung makin turbulen, yang dapat menyebabkan entitas bisnis tidak lagi berkelanjutan. Dalam kondisi yang semakin turbulen, dunia bisnis memerlukan kredibilitas dan integritas yang semakin tinggi, yang tidak hanya dapat diperoleh dari sisi internal bisnis, namun juga memerlukan faktor fundamental ekonomi makro yang kuat.

Dalam dunia bisnis setidaknya ada 4 faktor yang akan mempengaruhi strategi bisnis global (www.bized. co.uk) yaitu: (i) politik; (ii) ekonomi, yang terdiri dari sistem pajak, iklim investasi, pasar keuangan yang canggih yang memudahkan kapital untuk bergerak, harga komoditas, kebijakan fiskal dan moneter yang diambil oleh pemerintah, regulasi dan birokrasi internal, serta nilai tukar; (ii) teknologi; dan (iii) faktor sosial. Internasionalisasi bisnis sendiri pada dasarnya dapat memanfaatkan skema blok perdagangan untuk mengakselerasi bisnis. Blok perdagangan akan mempengaruhi akses ke pasar yang baru dan mempengaruhi biaya perdagangan relatif dalam wilayah yang berbeda di dunia.

Ketika pasar yang lebih luas menjadi tujuan bisnis, maka stabilitas nilai tukar menjadi faktor pendukung yang penting untuk diperhatikan. Salah satu ukuran dari risiko nilai tukar adalah volatilitas nilai tukar. Semakin besar volatilitas nilai tukar, berarti semakin tidak stabil dan berisiko, sehingga akan menghambat intervensi ke pasar luar negeri. Ketidakstabilan nilai tukar menjadi banyak diperhatikan terutama dalam integrasi ekonomi, karena integrasi perdagangan dipandang tidak lagi memadai untuk membendung arus globalisasi ekonomi yang terjadi. Tulisan ini, dengan mengolah data dari IFS dan ASEAN Secretariat, akan mengamati daya dukung ekonomi makro, terutama berkaitan dengan kondisi volatilitas nilai tukar di ASEAN, dan juga melihat apakah ASEAN telah siap melakukan integrasi keuangan untuk mengurangi volatilitas nilai tukar.

\section{TINJAUAN LITERATUT}

\subsection{Volatilitas Nilai Tukar dan Impaknya}

Penetapan nilai tukar memiliki dua rejim utama yaitu sistem nilai tukar tetap dan sistem nilai tukar mengambang. Secara luas telah dipercaya bahwa adopsi sistem nilai tukar mengambang setelah runtuhnya sistem Bretton Woods pada tahun 1973 menaikkan ketidakpastian nilai tukar. Sifat yang paling menonjol dari nilai tukar adalah pergerakannya yang sangat sensitif terhadap perubahan-perubahan politik dan ekonomi. Nilai tukar yang fluktuatif akan mengganggu pengambil keputusan dalam menetapkan harga jual dan akan menghasilkan ketidaklikuid dari sektor finansial, penurunan output dan peningkatan tekanan inflasi Salah satu cara untuk mengukur perilaku nilai tukar adalah menggunakan volatilitas ${ }^{2}$ nilai tukar. Volatilitas menunjukkan tingkat kecenderungan nilai tukar untuk berubah dan diyakini sebagai salah satu pemicu ekonomi biaya tinggi. Ketidakpastian ini mendorong pelaku usaha untuk menutup risiko dengan memasang harga tinggi sehingga berimplikasi pada daya saing bisnis yang menjadi relatif rendah.

Dewasa ini terdapat 3 pendekatan dalam pengukuran volatilitas nilai tukar. Yang pertama adalah dengan menggunakan standar deviasi dari level atau perubahan nilai tukar (Bahmani-Oskooee dan Ltaifa, 1992; Chowdury, 1993; dan Stokman, 1995), yang kedua adalah dengan mengukur ketidakpastian nilai tukar dengan menggunakan jarak antara nilai tukar spot dan forward (Hooper dan Kohlhagen, 1978), dan yang terakhir adalah dengan menggunakan model ARCH dan GARCH (Arize, 1995; Pozo, 1992). Keunggulan pemakaian ARCH dan GARCH dalam pengukuran volatilitas adalah menghilangkan kondisi perubahan nilai tukar yang independen karena menggunakan model parametrik yang varians time-varying, dan meliput proses stokastik yang terjadi pada nilai tukar Caporale dan Doroodian (1994).

2 Definisi volatilitas berbeda dengan fluktuasi dan depresiasi/apresiasi. Volatilitas diukur berdasarkan unsur standar

deviasi atau varians, fluktuasi diukur dengan melihat perbedaan nilai aktual dan nilai trend $\left[\frac{e_{t}-\hat{e}_{t}}{\hat{e}_{t}}\right]$, sedangkan depresiasi atau apresiasi dihitung dengan melihat perbedaan nilai aktual dengan nilai periode sebelumnya $\left[\frac{e_{t}-e_{t-1}}{e_{t-1}}\right]$. 
Pengukuran volatilitas dengan menggunakan standar deviasi nilai tukar dapat dilakukan melalui standar deviasi dari prosentase perubahan nilai tukar. Pendekatan yang lain dengan menggunakan moving average standard deviation (MASD) yang mempertimbangkan pergerakan ketidakpastian nilai tukar sepanjang waktu. Pendekatan MASD nilai tukar dapat dituliskan dalam bentuk berikut.

$$
V_{t}=\left[(1 / m) \sum_{i=1}^{m}\left(e_{t+i-1}-e_{t+i-2}\right)\right]^{1 / 2}
$$

Dimana e adalah log nilai tukar dan $\mathrm{m}$ adalah derajat rata-rata bergerak. Derajat rata-rata bergerak yang digunakan dalam penelitian ini ditentukan berdasarkan hasil smoothing yang terbaik.

Alternatif ketiga pengukuran volatilitas nilai tukar didasarkan pada model the autoregressive conditional heteroscedasticity $(\mathrm{ARCH})$ untuk nilai tukar.

$$
\begin{aligned}
& \Delta e_{t}=\delta_{0}+\sum_{i=1}^{n} \delta_{i} \Delta e_{t-i}+\mu_{t} \\
& V_{t}=h_{t}^{2}=\lambda_{0}+\sum_{j=i}^{q} \lambda_{j} \mu_{t-j}^{2}+v_{t}
\end{aligned}
$$

Persamaan (2) dan (3) diestimasi secara simultan dengan metode maximum likelihood. Nilai $\lambda_{0}$ dan $\lambda_{\mathrm{i}}$ diasumsikan positif, dengan $0<\lambda<1$ sehingga conditional variance merupakan proses yang stasioner. Pemilihan jenis pengukuran volatilitas ditentukan oleh nilai Akaike Information Criterion (AIC), dan pola data yang paling pas dengan pergerakan nilai tukar.

Volatilitas nilai tukar merupakan hal yang penting untuk diamati karena akan berpengaruh terhadap perdagangan internasional maupun investasi asing yang masuk. Penelitian Hviding, et al (2004) dengan menggunakan faktor-faktor yang menjadi determinan volatilitas nilai tukar menemukan bahwa: (i) besar kecilnya volatilitas nilai tukar dapat diterangkan melalui volatilitas fundamental ekonomi makro; (ii) perbedaan volatilitas nilai tukar antar negara biasanya terkait dengan variabel ekonomi makro seperti pengukuran pengawasan kapital, rejim nilai tukar asing dan struktur pasar; dan (iii) pilihan rejim nilai tukar yang tepat akan mengurangi volatilitas mata uang. Volatilitas nilai tukar memiliki hubungan yang penting dengan Neraca Perdagangan, karena berhubungan secara langsung dengan siklus bisnis (Barkolaus et.al, 2002) melalui biaya ketidakpastian dan penyesuaian, dan secara tidak langsung melalui efeknya terhadap struktur output, investasi dan kebijakan pemerintah (Agolli, 2002). Keterkaitan antara volatilitas nilai tukar dan aliran perdagangan internasional menjadi semakin penting apabila suatu negara menganut sistem perekonomian terbuka. Hau (2002) menyatakan bahwa integrasi perdagangan dan volatilitas nilai tukar riil secara struktural berkait dan memiliki korelasi negatif. Semakin terbuka ekonomi, semakin fleksibel tingkat harga agregat yang akan mengurangi efek kejutan penawaran uang yang tidak diantisipasi, sehingga dampak yang lebih jauh adalah volatilitas nilai tukar riil akan semakin rendah.

Beberapa penelitian terdahulu menunjukkan hasil yang ambigu apakah volatilitas nilai tukar berpengaruh terhadap perdagangan atau tidak. Penelitian Goeltom (1997) di Indonesia menunjukkan bahwa ketika rejim nilai tukar yang digunakan adalah mengambang terkendali, maka volatilitas nilai tukar tidak memberikan pengaruh yang signifikan terhadap perdagangan, sedangkan penelitian Susilo (2001) menunjukkan pada waktu rejim nilai tukar yang digunakan Indonesia adalah mengambang bebas, maka volatilitas nilai tukar memberikan pengaruh yang signifikan terhadap perdagangan pada jangka panjang, namun tidak pada jangka pendek. Penelitian Rahutami dan Kusumastuti (2007), menunjukkan bahwa pengaruh volatilitas pada perdagangan terjadi hanya antara Indonesia dengan negara-negara tertentu saja. Beberapa studi lainnya di luar kasus Indonesia menemukan bahwa ketidakpastian nilai tukar berdampak positif pada perdagangan internasional (Asseery and Peel, 1991; IMF, 1984), sementara penelitian Aristotelous (2001),Gagnon (1993) dan Bailey dkk (1986) menunjukkan tidak ada 
bukti bahwa volatilitas berdampak signifikan pada volume perdagangan. Menurut Cote (1994) hasil yang ambigu dari penelitian mengenai pengaruh volatilitas nilai tukar terhadap perdagangan disebabkan karena perbedaan alat ukur dan metode pengukuran volatilitas serta karena semakin majunya sektor keuangan maka dimungkinkan dilakukannya hedging, sehingga risiko bias dikurangi.

\subsection{Blok Perdagangan Tidak Lagi Cukup: Perlunya Mata Uang Tunggal}

Pentingnya kepastian nilai tukar dalam perekonomian global menyebabkan kebutuhan intergrasi ekonomi tidak lagi hanya berupa integrasi perdagangan namun berkembang menjadi integrasi keuangan. Integrasi keuangan secara penuh terjadi pada saat masing-masing negara dalam kawasan tersebut telah menghadapi kebijakan yang sama dalam keuangan (single set of rules), di mana investor dan penerbit aset keuangan mempunyai akses yang sama terhadap pasar keuangan (equal access) dan diperlakukan secara sama (treated equally) ketika beroperasi di sektor keuangan (Baele et al. 2004). Integrasi keuangan merupakan suatu upaya mengurangi dan menghapus hambatan arus keuangan antar negara di sebuah kawasan. Integrasi keuangan ini juga membutuhkan pengembangan infrastruktur keuangan regional untuk mendukung kelancaran dan meningkatkan transaksi keuangan lintas batas serta memelihara kestabilan keuangan dan nilai tukar di kawasan. Dalam jangka panjang integrasi keuangan dapat menuju kepada penyatuan dan integrasi moneter regional. Penyatuan mata uang berarti penghapusan rintangan untuk melakukan bisnis pada pasar yang besar, sehingga perdagangan dan investasi lintas negara akan meningkat. Pada tahap selanjutnya kondisi ini akan mendorong tingkat kompetisi industri dan pasar. Kompetisi bisnis akan membawa dampak yang baik karena akan memberikan oportunitas untuk mengembangkan bisnis, dan baik industri yang lemah, akan berusaha bekerja lebih keras untuk beradaptasi terhadap bisnis global.

Integrasi keuangan dalam definisi Krugman dan Obstfeld (2000) disebut sebagai Optimum Currency Area (OCA). OCA merupakan sebuah kelompok negara-negara dalam suatu kawasan yang perekonomiannya terkait erat, terutama karena faktor perdagangan dan mobilitas faktor produksi, yang menetapkan suatu nilai tukar tetap dan diantara negara-negara anggota dan ditandai dengan pembentukan mata uang tunggal. OCA dapat terbentuk dengan syarat berikut.

1. Interdependensi perdagangan. Interdependensi perdagangan perlu karena keseragaman nilai mata uang akan menghemat biaya transaksi dan mengurangi risiko yang berkaitan dengan penggunaan mata uang yang berbeda

2. Respon terhadap kejutan bersifat simetris. Negara-negara dengan respon terhadap kejutan yang simetris memungkinkan untuk mengambil kebijakan moneter yang sama. Determinan dari kejutan yang simetris ini adalah tingkat industri atau diversifikasi produk (Shin dan Wang ,2002)

3. Mobilitas faktor produksi. Adanya mobilitas faktor produksi diantara negara-negara anggota akan dapat meredam kejutan di dalam negeri tanpa menimbulkan biaya penyesuaian yang tinggi.

4. Konvergensi kebijakan makroekonomi. Apabila tidak ada konvergensi dalam kebijakan ekonomi, maka negara-negara dalam kawasan tersebut akan menghasilkan respon kebijakan yang mungkin saling bertolak belakang.

Secara empiris, tidak semua integrasi ekonomi mampu menghasilkan integrasi keuangan yang sukses. Berdasarkan best practice yang dilakukan oleh Uni Eropa, maka salah satu alasan digunakannya Economic and Monetary Union (EMU) adalah untuk medorong keterbukaan ekonomi yang lebih besar dan stabilitas nilai tukar yang lebih tinggi di kalangan negara anggota. Risiko mata uang yang mengakibatkan menurunnya perdagangan memotivasi penyatuan mata uang di Eropa (EU Commission, 1990) dan secara kuat berhubungan dengan intervensi pasar uang oleh bank sentral (Bayoumi and Eichengreen 1998). Inggris berminat masuk ke EMU karena tindakan ini akan berdampak pada sektor bisnis, dan pada akhirnya akan memperbaiki kinerja industri Inggris secara keseluruhan. Bergabungnya Inggris ke EMU juga memiliki implikasi makroekonomi yang penting bagi industri Inggris. Hilangnya kebijakan moneter yang independen dan fleksibilitas nilai tukar nominal akan secara fundamental merubah perekonomian dalam menyesuaikan diri terhadap perubahan ekonomi dan kejutan ekonomi 
yang tidak diinginkan. Sebagian besar penyesuaian ini akan terjadi melalui perubahan kondisi industri. Analisis mengenai bagaimana mata uang tunggal memiliki efek terhadap kondisi penawaran terlihat pada sektor bisnis Inggris yaitu (EU Commission, 1990)

1. Efek langsung adalah hilangnya biaya konversi mata uang, menurunnya volatilitas mata uang di kawasan Eropa, transparansi harga yang lebih tinggi

2. Efek jangka pendek dan menengah adalah menaikkan perdagangan, investasi dan perubahan mekanisme penyesuaian ekonomi

3. Efek jangka panjang adalah EMU mendorong kompetisi dan mempengaruhi tren dalam konsentrasi dan spesialisasi.

Penyatuan mata uang Euro melalui proses sepakat dan kontra terhadap stabilisasi nilai tukar. Namun setelah krisis Asia muncul argumentasi yang kuat bahwa ketika suatu negara menganut rejim nilai tukar yang fleksibel maka negara-negara tersebut perlu melakukan stabilisasi nilai tukar. Argumentasi teori menunjukkan bahwa nilai tukar yang fleksibel menyebabkan nilai tukar lebih mudah menyesuaikan kejutan asimetrik pada suatu perekonomian, sedangkan dari perspektif ekonomi mikro, volatilitas nilai tukar yang rendah berhubungan dengan biaya transaksi perdangangan internasional dan aliran modal yang rendah yang akan mendorong pertumbuhan ekonomi yang lebih tinggi. Adanya mata uang tunggal juga memberi manfaat semacam rejim nilai tukar tetap dan akan menghindarkan negara dari fenomena depresiasi "beggar-thy-neighbour" dalam integrasi ekonomi

\subsection{ASEAN : dari FTA ke AEC}

Di kawasan Asia Tenggara, globalisasi ekonomi juga memicu terbentuknya integrasi perdagangan regional. ASEAN Free Trade Area (AFTA) merupakan salah satu bentuk kerja sama ekonomi di antara negara-negara di kawasan Asia Tenggara (ASEAN). Kerjasama ASEAN itu sendiri sudah dimulai sejak tahun 1967. Pada awalnya, kerja sama ASEAN lebih merupakan kerjasama bidang politik, tetapi kemudian berkembang ke bidang-bidang yang lebih luas, termasuk bidang ekonomi. Perkembangan kerja sama berawal dari bentuk Preferential Trade Arrangement (PTA) kemudian berkembang menjadi Free Trade Area (FTA) yang didukung dengan skema Common Efective Preferential Tarif (CEPT). Pada dasarnya pengaturan lebih ditekankan pada pengaturan tarif dan non tarif, serta pengaturan pelengkap misalnya berupa rule of origin.

Perkembangan terakhir kerjasama ASEAN adalah berupa pembentukan ASEAN Economic Community (AEC). Visi ini lebih dipertegas dalam KKT ASEAN Oktober 2003 di Bali dalam Deklarasi ASEAN Concord II (Bali Concord II) yang menyatakan pembentukan komunitas ASEAN yang tediri dari 3 hal utama, yaitu ASEAN Economic Community (AEC), ASEAN Security Community (ASC), dan ASEAN Socio-Cultural Community (ASCC). AEC merupakan realisasi dari aspirasi ASEAN sebagai kawasan yang stabil, makmur, mempunyai daya kompetitif yang tinggi. AEC akan berfungsi sebagai pasar tunggal dan wilayah basis produksi pada tahun 2020. Program yang ditujukan di AEC tidak saja meliputi kebebasan aliran barang, tenaga kerja, aliran modal, namun juga untuk mengurangi kemiskinan serta kesenjangan sosial ekonomi.

Untuk menfasilitasi pencapaian AEC sesuai dengan target maka dilakukan Pertemuan tingkat menteri keuangan ASEAN (AFMM) ke 7 Agustus 2003 di Makati City Filipina menyepati Roadmap integrasi ASEAN (RIA) bidang finansial (RIA-Fin) yang meliputi 4 sektor, yaitu,

1. pengembangan pasar modal

2. liberalisasi neraca modal

3. liberalisasi jasa keuangan

4. kerja sama nilai tukar

Berkaitan dengan volatilitas mata uang maka RIA yang menarik untuk diamati lebih lanjut adalah kerjasama nilai tukar. Roadmap kerja sama nilai tukar bertujuan untuk mewujudkan kerja sama mata uang yang lebih erat untuk meningkatkan perdagangan intra kawasan dan memperdalam integrasi ekonomi regional. Seperti dikemukakan di awal, sebuah integrasi ekonomi akan menjadi semakin kuat apabila dilakukan integrasi keuangan. Data-data berikut ini akan memberikan indikasi pentingnya integrasi keuangan di ASEAN dan kemungkinan kesiapan ASEAN 
menuju integrasi keuangan tersebut.

\section{ANALISIS DATA DAN PEMBAHASAN}

\subsection{Volatilitas Mata Uang Indonesia dan Negara-Negara ASEAN}

Integrasi ekonomi ASEAN menghadapi tantangan besar karena negara-negara ASEAN memiliki sistem ekonomi, pendapatan perkapita, tingkat pembangunan ekonomi dan institusi serta kondisi sosial yang berbeda dan heterogen. Perbedaan dan heterogenitas menyebabkan beberapa negara yang tidak memiliki infrastruktur dan kapasitas institusional yang memadai mengalami kesulitan untuk berintegrasi dengan negara yang lain. Salah satu kondisi yang berbeda dan heterogen adalah mata uang. Setiap negara memiliki mata uang yang berbeda dan sistem nilai tukar yang berbeda. Kondisi ini menyebabkan fungsi reaksi nilai tukar yang asimetrik, yang akan membuat sebagian negara mampu menyesuaikan dan menstabilkan nilai tukar secara cepat sedangkan yang lain tidak.

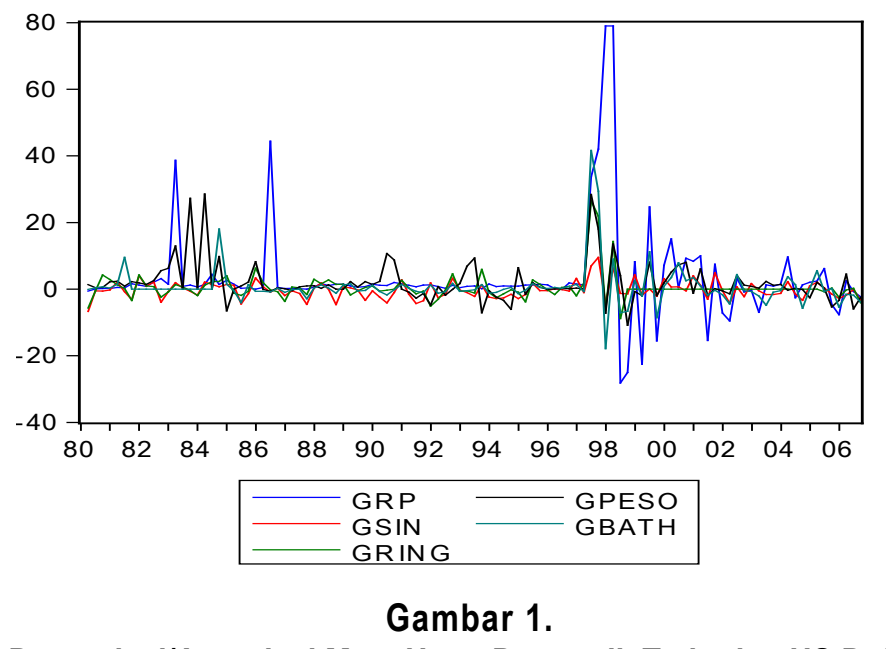

Depresiasi/Apresiasi Mata Uang Domestik Terhadap US Dollar $1980.1-2006.4$

Gambar 1 menunjukkan data depresiasi atau apresiasi yang dialami oleh tiap negara anggota ASEAN 5 terhadap US\$, yang terdiri dari Indonesia, Singapura, Malaysia, Philipina dan Thailand. Dalam ASEAN 5 terlihat bahwa Indonesia merupakan negara yang mengalami pergerakan mata uang domestik terhadap US\$ yang paling fluktuatif. Pada saat krisis menimpa ASEAN mulai dari kuartal 3 tahun 1997, terlihat bahwa Rupiah terdepresiasi mulai dari 33,67\% dan mencapai puncaknya pada 1998.2 dengan depresiasi sebesar 78,97\%. Thailand, sebagai negara yang dikatakan terkena krisis paling awal dan merambat ke negara lain, mengalami depresiasi Bath yang relatif lebih kecil yaitu 41,61\% namun kemudian berhasil menekan depresiasi menjadi 9,04\% pada 1998.2. Ringgit dan Peso juga terdepresiasi terhadap dolar namun tidak separah Indonesia. Singapura merupakan negara yang relatif stabil, sehingga pada masa krisis hanya terdepresiasi sebesar $6 \%$. Negara-negara ASEAN ${ }^{3}$ lainnya yaitu Kamboja (Riels), Vietnam (Dong), Myanmar (Kyats) dan Laos (Kip) juga mengalami depresiasi. Vietnam mengalami depresiasi tertinggi pada tahun 1987, namun lebih disebabakan karena perubahan mata uang.

Bila dilihat dari sisi volatilitas ${ }^{4}$ mata uang domestik terhadap US\$ tampak bahwa ketika masa krisis ekonomi mata uang yang paling volatile adalah Bath, Rupiah (tertinggi) dan Kip. Singapura dalam sebaran data terlihat cukup volatile namun secara prosentase sangat kecil, tidak pernah melebihi $8 \%$. Kondisi ini menunjukkan bahwa

3 Brunei tidak diikutkan dalam analisis volatilitas karena ketidaklengkapan data

4 Dalam tulisan ini volatilitas dihitung dengan menggunakan MASD karena dibandingkan dengan perubahan standar deviasi dan GARCH, MASD memiliki nilai AIC yang paling kecil dan paling pas terhadap data aktual. 
risiko mata uang Singapura dan Brunei terhadap US\$ paling kecil. Dalam 2 tahun terakhir volatilitas masing-masing negara telah relatif stabil.
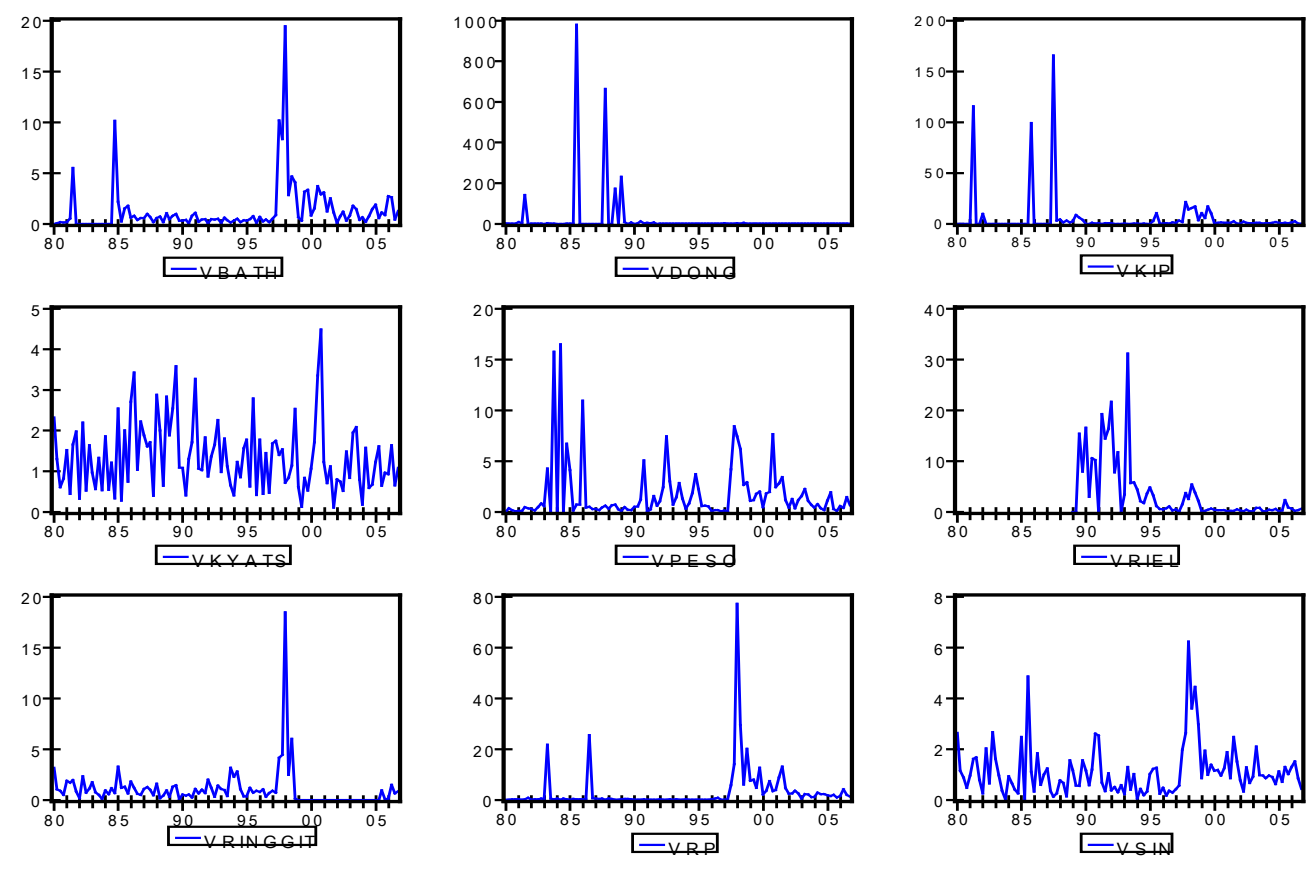

Gambar 2.

Volatilitas Mata Uang Domestik terhadap US Dollar $1980.1-2006.4$

Bila Indonesia memiliki tingkat depresiasi dan volatilitas nilai tukar yang relatif rentan dibandingkan negaranegara lain di ASEAN, maka hal berikutnya yang harus diperhatikan adalah bagaimana pergerakan Rupiah terhadap mata uang negara-negara ASEAN yang lain. Untuk melihat kondisi nilai tukar Rupiah terhadap mata uang negara ASEAN lain, maka dilakukan periodisasi yang mencerminkan kondisi kebijakan moneter di Indonesia. Periodisasi yang dilakukan adalah sebagai berikut.

1. Tahun 1980.1-1989.4. Terjadi deregulasi dan liberalisasi finansial, perbankan Indonesia mulai tumbuh pesat, dan terjadi kebijakan diskresi akibat tekanan BOP.

2. Tahun 1990.1-1994.4. Kebijakan moneter yang menonjol pada periode ini adalah kebijakan uang ketat.

3. Tahun 1995.1-1997.2. Kebijakan moneter yang dilakukan pada saat ini cenderung diskresi karena untuk mengatasi inflasi.

4. Tahun 1997.3-1999.4. Pada periode ini dilakukan kebijakan krisis ekonomi, yang ditandai dengan pengetatan suku bunga. Pada periode ini juga merupakan awal dari pergantian sistem nilai tukar menjadi sistem nilai tukar mengambang bebas/

5. Tahun 2000.1-2006.4. Pada periode ini dilakukan kebijakan untuk menjaga stabilitas dan pemulihan ekonomi. Kebijakan suku bunga dan uang beredar tidak lagi terlalu ketat, bahkan pada awal periode dapat dikatakan terlalu longgar. 
Tabel 1.

Posisi Rupiah terhadap Mata Uang Asing

\begin{tabular}{ccccccc}
\hline Mata & \multirow{2}{*}{ Ukuran } & $1980.1-$ & $1990.1-$ & $1995.1-$ & $1997.3-$ & $\mathbf{2 0 0 0 . 1 -}$ \\
uang & & 1989.4 & 1994.4 & 1997.2 & 1999.4 & $\mathbf{2 0 0 6 . 4}$ \\
\hline \multirow{2}{*}{ US\$ } & rata-rata & $1.149,95$ & $2.024,45$ & $2.331,90$ & $8.075,70$ & $9,265,25$ \\
& maksimum & $1.797,00$ & $2.200,00$ & $2.450,00$ & $14.900,00$ & $11.440,00$ \\
\multirow{2}{*}{ Bath } & rata-rata & 46,60 & 79,79 & 92,14 & 205,27 & 225,68 \\
& maksimum & 69,95 & 87,68 & 95,00 & 352,14 & 253,07 \\
Peso & rata-rata & 74,88 & 77,28 & 89,15 & 202,19 & 178,49 \\
& maksimum & 89,26 & 90,10 & 92,86 & 353,99 & 218,46 \\
Ringgit & rata-rata & 461,39 & 767,18 & 929,17 & $2.113,09$ & $2.454,28$ \\
& maksimum & 664,74 & 859,38 & 975,80 & $3.574,00$ & $3.010,53$ \\
\multirow{2}{*}{ Sin\$ } & rata-rata & 551,97 & $1.232,01$ & $1.647,79$ & $4.815,84$ & $5.414,59$ \\
& maksimum & 948,59 & $1.506,13$ & $1.713,29$ & $8.729,79$ & $6.283,30$ \\
Dong & rata-rata & 635,16 & 0,21 & 0,21 & 0,60 & 0,60 \\
& maksimum & $2.487,08$ & 0,34 & 0,21 & 1,15 & 0,77 \\
\multirow{2}{*}{ Kip } & rata-rata & 22,85 & 2,84 & 2,57 & 1,90 & 0,95 \\
& maksimum & 62,90 & 3,06 & 3,09 & 3,28 & 1,32 \\
\multirow{2}{*}{ Kyat } & rata-rata & 162,51 & 332,72 & 401,83 & $1.290,70$ & $1.516,36$ \\
& maksimum & 277,55 & 377,47 & 414,11 & $2.331,79$ & $1.756,36$ \\
\multirow{2}{*}{ Riel } & rata-rata & 10,31 & 2,08 & 0,90 & 2,15 & 2,32 \\
& maksimum & 11,82 & 5,28 & 0,96 & 3,73 & 2,92 \\
\hline
\end{tabular}

Sumber: IFS, dan ASEAN Secreatariat, diolah

Posisi nilai tukar Rupiah bila dibandingkan dengan negara-negara ASEAN 5, memang cenderung lebih rendah. Pada masa krisis ekonomi (1997.3-1999.4), rata-rata nilai tukar Rupiah terhadap Singapura \$ sebesar Rp 4.815,84 dan maksimumnya mencapia Rp 8.729,29, sedangkan dengan Thailand dan Philipina relatif rendah, meskipun untuk 1 Bath dan 1 Peso, Rupiah yang harus ditukarkan sebesar Rp 205,27 dan Rp 202,19. Kondisi 6 tahun terakhir ini secara rata-rata tidak menunjukkan perbaikan kinerja nilai tukar Rupiah. Depresiasi tetap terjadi sehingga rata-rata nilai tukar Rupiah terhadap Sin\$ adalah Rp 5.414,59, terhadap ringgit sebesar Rp 2.454,28, terhadap Peso dan Bath masing-masing Rp 253,07 dan Rp 225,68. Bila dibandingkan dengan periode sebelum sistem nilai tukar dilepas, maka terlihat bahwa nilai tukar rata-rata saat ini jauh lebih buruk dibandingkan periode sebelumnya. Hal ini menunjukkan bahwa pengaruh intervensi Bank Indonesia terhadap stabilitas kurs sangat besar, sehingga ketika Bank Indonesia tidak lagi boleh melakukan intervensi, harga Rupiah hanya disangga oleh kinerja ekspor dan impor. Depresiasi sangat mungkin terjadi karena ekspor Indonesia relatif kurang kompetitif, dan ketergantungan Indonesia terhadap impor barang antara masih sangat besar. Nilai tukar Indonesia dibandingkan dengan negara ASEAN lainnya, juga relatif tidak menggembirakan. 
Tabel 2.

Volatilitas Rupiah terhadap Mata Uang Asing

\begin{tabular}{ccccccc}
\hline Mata & Ukuran & $\mathbf{1 9 8 0 . 1 -}$ & $\mathbf{1 9 9 0 . 1 -}$ & $\mathbf{1 9 9 5 . 1 -}$ & $\mathbf{1 9 9 7 . 3 -}$ & $\mathbf{2 0 0 0 . 1 -}$ \\
uang & $\mathbf{1 9 8 9 . 4}$ & $\mathbf{1 9 9 4 . 4}$ & $\mathbf{1 9 9 7 . 2}$ & $\mathbf{1 9 9 9 . 4}$ & $\mathbf{2 0 0 6 . 4}$ \\
\hline \multirow{2}{*}{ US\$ } & rata-rata & 1,451 & 0,109 & 0,208 & 18,549 & 3,131 \\
& maksimum & 25,527 & 0,237 & 0,821 & 77,195 & 13,064 \\
Bath & rata-rata & 1,971 & 0,352 & 0,549 & 14,763 & 2,534 \\
& maksimum & 25,576 & 1,061 & 1,217 & 49,301 & 13,041 \\
Peso & rata-rata & 2,709 & 1,784 & 0,583 & 16,894 & 2,740 \\
& maksimum & 25,465 & 7,185 & 2,199 & 66,367 & 13,774 \\
Ringgit & rata-rata & 2,189 & 1,079 & 0,875 & 15,442 & 3,069 \\
& maksimum & 24,804 & 2,920 & 1,197 & 52,034 & 13,064 \\
\multirow{2}{*}{ Sin\$ } & rata-rata & 2,152 & 0,763 & 0,712 & 16,909 & 2,730 \\
& maksimum & 24,847 & 2,464 & 1,229 & 68,983 & 11,701 \\
Dong & rata-rata & 8,245 & 1,612 & 0,464 & 19,074 & 3,125 \\
& maksimum & 55,578 & 9,794 & 2,103 & 78,671 & 13,299 \\
\multirow{2}{*}{ Kip } & rata-rata & 5,330 & 0,227 & 1,853 & 19,707 & 2,796 \\
& maksimum & 42,580 & 0,899 & 8,800 & 52,222 & 12,784 \\
\multirow{2}{*}{ Kyat } & rata-rata & 2,539 & 1,279 & 1,362 & 18,550 & 3,088 \\
& maksimum & 25,278 & 3,090 & 2,681 & 76,984 & 12,560 \\
\multirow{2}{*}{ Riel } & rata-rata & 6,631 & 8,393 & 1,427 & 17,856 & 3,187 \\
& maksimum & 12,404 & 29,367 & 5,157 & 72,157 & 12,939 \\
\hline
\end{tabular}

Sumber: IFS, dan ASEAN Secreatariat, diolah

Dari sisi volatilitas rupiah terhadap mata uang asing terlihat bahwa pada periode 2000.1-2006.4 volatilitas Rupiah dibawah 4\%, namun nilai maksimumnya di atas 10\%. Hal ini menunjukkan bahwa pada periode setelah krisis ekonomi Rupiah masih memiliki risiko yang relatif tinggi, dan bergerak secara fluktuatif. Dibandingkan dengan kondisi pada masa krisis memang terlihat bahwa Bank Indonesia mampu menstabilkan nilai Rupiah dengan baik, karena selama periode krisis volatilitas Rupiah sangat tinggi. Namun bila dibandingkan dengan periode 1990-1997, dimana rejim nilai tukar yang digunakan adalah nilai tukar mengambang terkendali, maka terlihat bahwa perubahan rejim nilai tukar mendorong fluktuasi Rupiah yang jauh lebih besar. Kondisi ini sesuai dengan teori, karena pada saat nilai tukar fleksibel, maka stabilitas nilai tukar itu akan sangat bergantung pada perilaku permintaan dan penawaran valuta asing. Pada periode sebelum tahun 1990 terlihat volatilitas rupiah yang cenderung lebih tinggi dibanding dengan periode 1990-1997, karena pada saat itu terjadi tekanan terhadap BOP, dan adanya liberalisasi perbankan yang menekan nilai rupiah.

Data di atas menunjukkan adanya volatilitas mata uang domestik negara-negara ASEAN terhadap US\$ dan volatilitas Rupiah terhadap mata uang negara-negara ASEAN yang cenderung tinggi. kondisi ini akan memberikan biaya yang tinggi dalam transaksi perdagangan meskipun telah dilakukan integrasi perdagangan kawasan ASEAN. Biaya yang timbul ini akan menurunkan manfaat dari integrasi perdagangan, sehingga roadmap mengenai kerjasama nilai tukar merupakan hal yang patut untuk dipikirkan. Namun sesuai dengan teori kerjasama keuangan yang arah akhirnya akan menuju ke mata uang tunggal membutuhkan prasyarat setidaknya berupa interdependensi perdagangan dan reaksi yang simetris terhadap suatu kejutan. Terpenuhinya unsur-unsur tersebut akan memudahkan terjadinya integrasi keuangan di tingkat ASEAN.

\subsection{Aliran Perdagangan di ASEAN}

Aktivitas perdagangan ASEAN dari tahun ke tahun semakin meningkat. Proporsi aliran perdagangan intra ASEAN jauh lebih kecil dibandingkan aliran perdagangan ekstra ASEAN, namun demikian menunjukkan tren yang meningkat. Nilai ekspor intra dan ekstra ASEAN cenderung lebih besar dibandingkan dengan impornya. 
Pada tahun 2005 dan 2006 ekspor intra trade ASEAN mencapai 165.064,29 juta US\$ dan 194.725,02 juta US\$, sedangkan impor intra ASEAN mencapai $141.614,81$ juta US\$ dan $185.654,39$ juta US\$. Perdagangan ekstra ASEAN memiliki nilai yang lebih tinggi. Ekspor pada tahun 2005 dan 2006 mencapai 486.235,62 juta US\$ dan $586.435,45$ juta US\$ , sedangkan impornya mencapai $440.214,08$ juta US $\$$ dan $515.493,42$ juta US\$.Pola perdagangan baik intra maupun ekstra mengikuti pola yang sama. Pada waktu terjadi krisis ekonomi, perdagangan ASEAN cenderung mengalami penurunan.

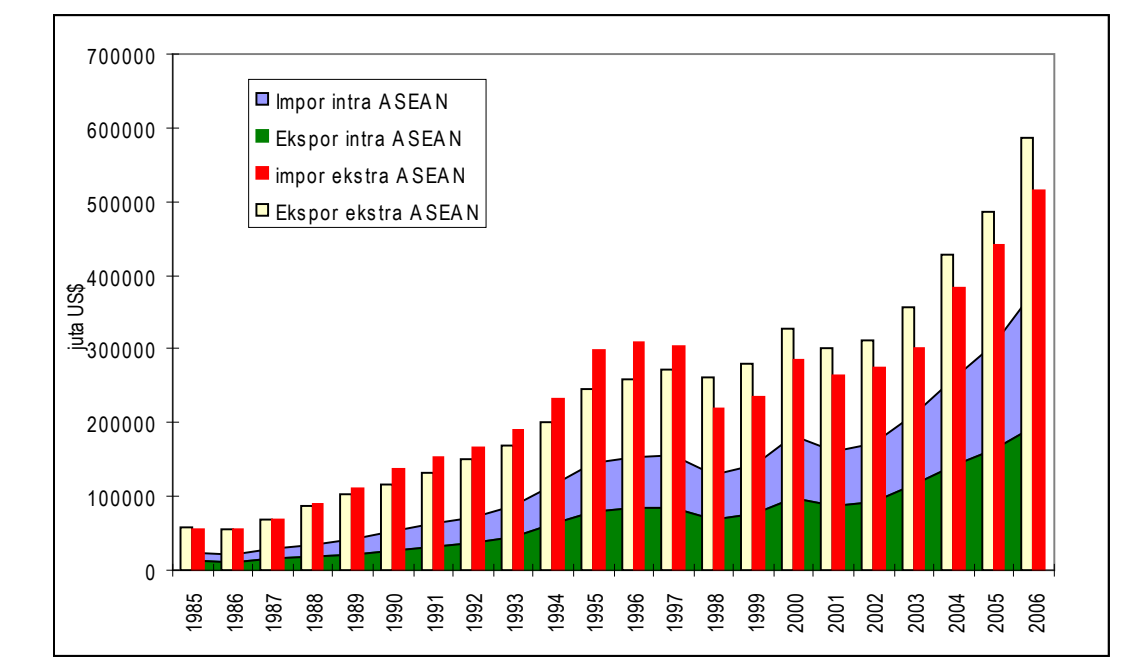

Sumber: ASEAN Secreatariat

\section{Gambar 3.}

\section{Aliran Perdagangan ASEAN}

Negara yang mendominasi aliran perdagangan intra ASEAN adalah Singapura. Pangsa ekspor Singapura ke ASEAN mencapai 44,16\%, 43,61\% dan 43,10\% pada tahun 2004, 2005, dan 2006. sedangkan pangsa impornya mencapai $39,34 \%, 36,82 \%$, dan 33,58. Proporsi ekspor Indonesia ke ASEAN tidaklah setinggi Malaysia dan Thailand. Pada tahun 2004, 2005 dan 2006, pangsa ekspor Indonesia mencapai9,16\%, 9,59\% dan 11,86\%, sedangkan impornya adalah 9,57\%, 12,03\% dan 20,46\%. Impor pada tahun 2006 lebih tinggi dibandingkan dengan Malaysia dan Thailand. Kondisi ini menunjukkan bahwa Indonesia memiliki intensitas impor yang jauh lebih besar, sedangkan dari sisi ekspornya kurang kompetitif, sehingga nilainya cenderung kecil. Negara-negara ASEAN lain di luar ASEAN 6, cenderung memiliki proporsi yang kecil.
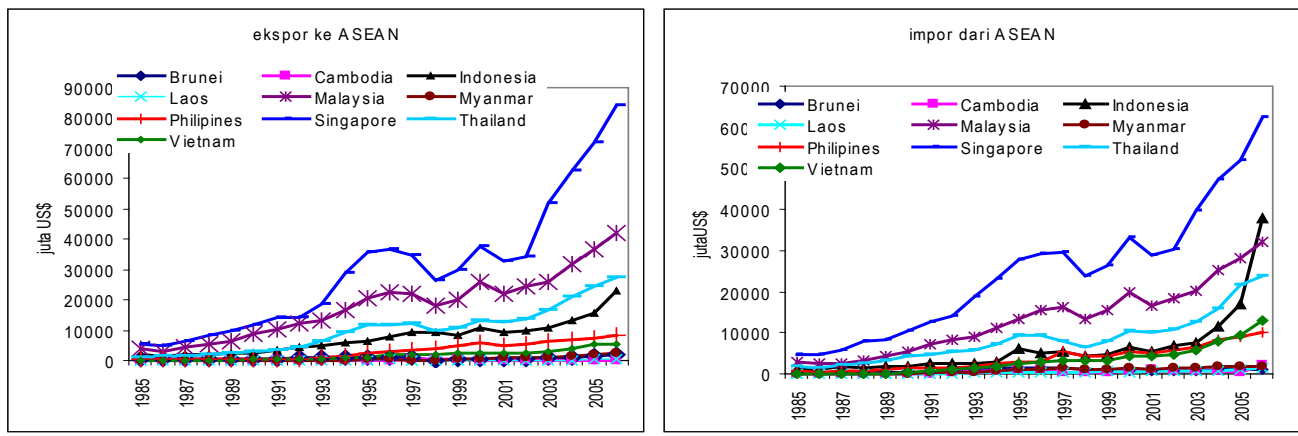

Sumber: ASEAN Secreatariat

\section{Gambar 4.}

Aliran Perdagangan ASEAN menurut Negara 
Aliran perdagangan Indonesia ke ASEAN pada tahun 2006 paling banyak dilakukan dengan Singapura. $58,11 \%$ pangsa ekspor Indonesia ditujukan ke Singapura, sedangkan impornya mencapai $72,11 \%$. Impor Indonesia dari Singapura didominasi oleh mesin dan barang-barang antara, sedangkan ekspornya didominasi oleh komoditas primer. Malaysia adalah negara kedua yang memiliki proporsi perdagangan terbesar dengan Indonesia, dimana pangsa ekpor Indonesia ke Malaysia mencapai 19,50\%, sedangkan impornya mencapai 11,80\%.
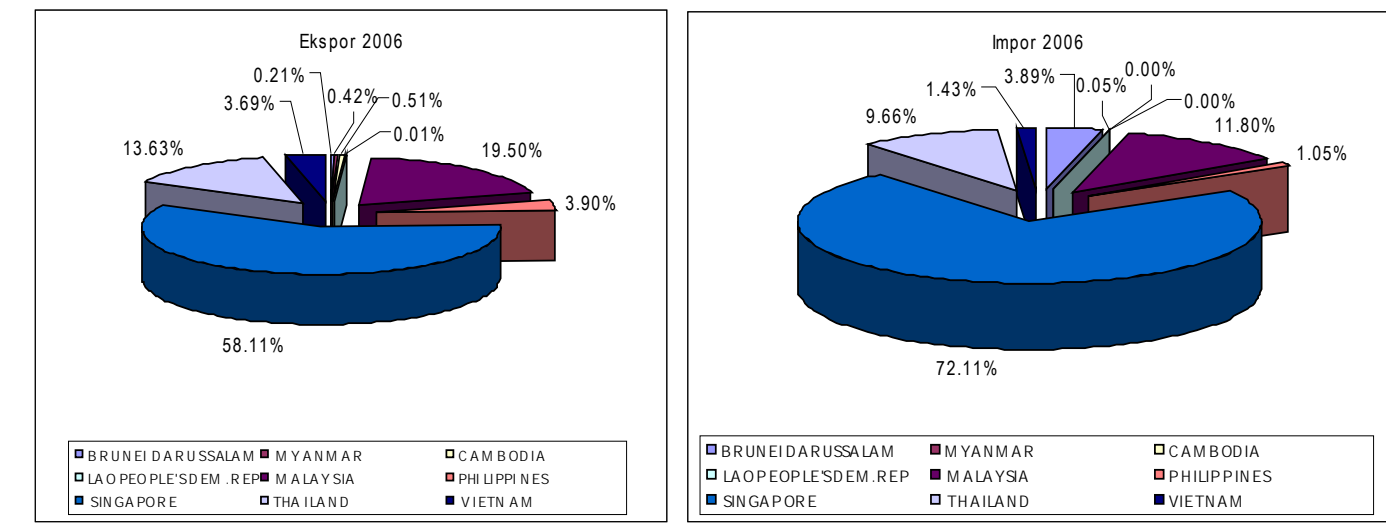

Sumber: ASEAN Secreatariat

\section{Gambar 5.}

Pangsa Ekspor Impor Indonesia ke Negara-negara ASEAN, 2006

Sebaran data aliran perdagangan ini menunjukkan bahwa intensitas perdagangan di kawasan ASEAN mengalami pertumbuhan yang signifikan. Kalau dilihat dari pangsa ekspor-impor intra ASEAN, maka perdagangan intraASEAN hanya sekitar $25 \%$, sedangkan sisanya mengalir ke dunia. Namun apabila dilihat tingat pertumbuhannya maka ekspor intraASEAN pada tahun 2004-2006, meningkat sebesar 21,48\%, 16,295 dan 17,96, sedangkan ekspor ekstra ASEAN meningkat sebesar 20,34\% 13,71\% dan 10,61\%. Impor intra ASEAN pada 2004-2006 mengalami peningkatan sebesar 25,45\%, 17,95\% dan 31,09\%, sedangkan impor ekstra ASEAN meningkat sebesar 26,69\%, $15,21 \%$ dan $17,10 \%$. Peningkatan ini menunjukkan adanya peluang bisnis yang besar di kawasan ASEAN sendiri maupun ke luar ASEAN.

\subsection{Reaksi Simetris terhadap Kejutan}

Reaksi simetris terhadap suatu kejutan akan menentukan sejauh mana kemudahan dan kecepatan suatu kawasan menuju konvergensi ekonomi karena menentukan biaya ekonomi yang timbul dalam rangka penyesuaian ekonomi sehubungan dengan tidak adanya independensi dalam kebijakan moneter dalam rangka mata uang tunggal. Mundell (1961) menyatakan, apabila negara-negara dalam kawasan mengalami kejutan yang berkorelasi positif, maka kawasan tersebut layak untuk melakukan penyatuan mata uang. Reaksi yang simetris dapat dilihat dari struktur ekonomi suatu negara. 
Tabel 3.

Indikator Ekonomi Makro Negara-negara ASEAN

\begin{tabular}{|c|c|c|c|c|c|c|c|c|c|c|}
\hline & Indonesia & Malaysia & Philipina & Singapura & Thailand & Laos & Myanmar & Viet Nam & Brunei & Kamboja \\
\hline 2006 & 103.964 .05 & $161,248.70$ & $47,037.00$ & $271,601.03$ & $129,948.48$ & 254.68 & $3,514.76$ & $39,605.00$ & $5,768.70$ & $2,602.37$ \\
\hline 2005 & $85,659.95$ & $140,470.48$ & $41,254.68$ & $229,804.14$ & 109.622 .59 & 174.08 & $3,123.84$ & 28.576 .49 & 6.369 .29 & $3,091.47$ \\
\hline 2006 & $78,392.71$ & $131,720.12$ & $51,523.00$ & 238.502 .99 & 126.848 .50 & 423.58 & $2,115.49$ & 44.410 .00 & $1,028.68$ & $2,147.02$ \\
\hline 2005 & $57,700.88$ & $114,213.13$ & $47,418.18$ & $200,162.80$ & $117,990.91$ & 701.85 & $1,632.87$ & $32,593.88$ & $1,503.11$ & $2,824.75$ \\
\hline 2006 & 13.10 & 4.00 & 6.30 & 1.00 & 4.60 & 7.30 & 11.70 & 7.20 & 0.10 & 4.70 \\
\hline 2005 & 10.50 & 3.10 & 7.60 & 0.50 & 4.50 & 6.80 & 10.50 & 8.60 & 1.20 & 5.80 \\
\hline 2002 & 11.90 & 1.80 & 3.00 & -0.40 & 0.60 & 10.20 & 57.10 & 3.80 & -2.30 & 3.20 \\
\hline 2006 & 9.71 & 3.19 & 5.09 & 0.57 & $3.25-4.75$ & 7.00 & 0.00 & 7.68 & 0.00 & 4.42 \\
\hline 2005 & 11.75 & 3.02 & 5.86 & 0.56 & $2.00-3.00$ & 6.75 & 9.50 & 7.68 & 0.97 & 4.84 \\
\hline 2002 & 13.63 & 3.20 & 3.86 & 0.78 & 1.75 & 12.00 & 9.50 & 6.80 & 0.40 & 4.89 \\
\hline 2006 & $297,080.00$ & 58.22 & 694.11 & 25.76 & 865.23 & $2,501.76$ & 0.00 & $230,756.00$ & & $3,382.79$ \\
\hline 2005 & $239,823.00$ & 52.62 & 446.81 & 23.40 & 842.52 & $1,823.14$ & $2,074.45$ & 174.504 .74 & & $2,637.15$ \\
\hline 2002 & $138,250.00$ & 42.58 & 356.08 & 19.96 & 632.74 & $1,079.13$ & 882.04 & $95,502.00$ & & $1,980.66$ \\
\hline 2006 & 5.55 & 5.93 & 5.33 & 7.88 & 5.03 & 7.30 & 7.00 & 8.17 & 5.14 & 5.00 \\
\hline 2005 & 5.60 & 5.00 & 4.87 & 6.62 & 4.49 & 7.27 & 4.50 & 8.43 & 0.39 & 13.63 \\
\hline 2002 & 4.25 & 4.35 & 4.43 & 4.16 & 5.32 & 5.93 & 5.50 & 7.04 & 3.87 & 5.25 \\
\hline 2006 & $1,640.43$ & $5,880.35$ & 1.351 .47 & $29,499.63$ & $3,167.80$ & 574.01 & 208.61 & 723.86 & 30.213 .55 & 512.34 \\
\hline 2005 & $1,278.55$ & $5,250.35$ & $1,158.62$ & $26,864.31$ & $2,720.79$ & 477.99 & 199.43 & 637.07 & $25,744.13$ & 451.97 \\
\hline 2002 & 970.41 & $3,899.46$ & 956.18 & $21,122.07$ & $2,020.39$ & 326.66 & 135.63 & 439.83 & $17,157.53$ & 307.37 \\
\hline 2006 & $1,846,654.90$ & 474.39 & $1,275.08$ & 209.68 & $4,044.82$ & $1,658.90$ & 144.14 & 425.088 .00 & 12.05 & $24,378.95$ \\
\hline 2005 & $1,749,546.90$ & 447.82 & $1,210.50$ & 194.37 & $3,851.30$ & $1,531.64$ & 134.72 & $392,988.97$ & 11.46 & $22,009.12$ \\
\hline 2002 & $1,504,380.60$ & 220.42 & $1,046.08$ & 162.49 & $3,237.04$ & $1,262.04$ & 116.82 & $313,135.00$ & 11.04 & $15,642.51$ \\
\hline 2006 & -0.60 & -4.40 & 0.10 & 1.90 & 2.70 & -0.40 & 0.00 & -1.60 & 4.90 & 0.00 \\
\hline 2005 & -0.50 & -3.80 & -2.70 & -0.30 & -0.60 & -4.50 & 0.00 & -1.60 & 15.00 & 1.20 \\
\hline 2002 & -1.50 & -5.60 & -5.40 & -1.10 & -1.40 & -4.10 & 0.00 & -2.40 & -3.60 & -3.70 \\
\hline 2006 & $8,995.00$ & 3.53 & 49.13 & 1.53 & 36.05 & $9,739.00$ & & $16,091.00$ & 1.53 & $4,065.00$ \\
\hline 2005 & $9,830.00$ & 3.78 & 53.07 & 1.66 & 41.03 & $10,805.00$ & & $15,875.00$ & 1.66 & $4,120.00$ \\
\hline 2002 & $8,940.00$ & 3.80 & 53.10 & 1.74 & 43.15 & $10,705.00$ & & $15,403.00$ & 1.73 & $3,990.00$ \\
\hline
\end{tabular}

Sumber: ASEAN Secreatariat

Data tabel 3 menunjukkan bahwa indikator-indikator ekonomi makro negara-negara ASEAN sangat heterogen dan berbeda satu dengan yang lain. Seperti pada indikator perdagangan, terdapat kesenjangan yang cukup besar antara ASEAN 5 dan negara ASEAN lainnya. Angka inflasi pun menunjukkan karakter yang sangat berbeda satu dengan yang lain. Inflasi singapura dan Brunei mampu ditekan sangat rendah sampai di bawah $2 \%$, sedangkan inflasi Indonesia masih cukup tinggi, demikian pula dengan inflasi Myanmar yang sangat tinggi. Kondisi ini menunjukkan kebijakan moneter yang digunakan untuk menstabilkan inflasi tidak memiliki efektivitas yang sama. Padahal salah satu syarat integrasi keuangan adalah adanya konvergensi kebijakan moneter. Sistem nilai tukar yang dianut oleh negara-negara ASEAN pun beragam, misalnya Indonesia menganut sistem nilai tukar mengambang, sedangkan Malaysia menggunakan sistem nilai tukar tetap. Kondisi ini menciptakan nilai tukar mata uang domestik terhadap US\$ sangat beragam. Indonesia berada pada kisaran di atas Rp 8.000,00 sedangkan Malaysia, Singapura dan Brunei sangat rendah dibawah Ring 4, Sin\$2, Brun\$2. Kondisi fiscal balance pun tidak jauh berbeda. Fiscal balance menunjukkan surplus/defisit anggaran per PDB. Indikator ini menunjukkan bahwa reaksi apabila terjadi kejutan tidak simetris sehingga tidak mampu mendukung integrasi keuangan secara instan.

\section{PENUTUP}

Kebutuhan untuk menjaga volatilitas nilai tukar merupakan faktor yang penting untuk menunjang globalisasi bisnis Indonesia. Nilai tukar yang volatile akan membebani biaya transaksi bisnis, dan akan menurunkan kemampuan bisnis berkompetisi di pasar internasional. Salah satu cara yang dapat dilakukan untuk menjaga volatilitas 
nilai tukar adalah dengan menggunakan skema kerjasama nilai tukar yang menjadi salah satu agenda dalam AEC. Permasalahannya adalah, indikator intensitas perdagangan (walaupun dari tahun ke tahun menunjukkan kecenderungan yang meningkat) dan reaksi yang simetris terhadap krisis tidak terlalu mendukung penerapan integrasi keuangan ASEAN dalam waktu singkat. Lemahnya konvergensi makroekonomi, belum memadainya kerangkan institusional regional dan masih rendahnya perdagangan intra kawasan ASEAN merupakan faktor yang menghambat pembentukan mata uang tunggal. Perbedaan tingkat pertumbuhan PDB, kondisi perdagangan dan kondisi fiskal balance dapat menimbulkan risiko konflik kepentingan terutama dikaitkan dengan tujuan peningkatan pertumbuhan ekonomi dan pengendalian inflasi dengan kepentingan bersama pencapaian tujuan kerja sama nilai tukar. Apabila integrasi keuangan dipaksakan maka risiko yang cukup tinggi akan menyebabkan kerja sama tidak berkesinambungan. Untuk itu Indonesia masih harus berupaya menjaga stabilitas nilai tukar melalui kebijakankebijakan moneter yang tepat, dan mengupayakan sinergi yang lebih kuat lagi dengan negara-negara anggota ASEAN yang lain.

\section{DAFTAR PUSTAKA}

Agolli, Mimoza (2002), "Exchange Rate Volatility Effect On Trade Variations", Working Paper.1-18

Aristotelous, K (2001), "Exchange Rate Volatility, Exchange Rate Regime, And Trade Volume: Evidence From The UK-US Export Function (1989-1999)", Economics Letters, 72:87-94.

Arize, A.C. (1995), "The Effects Of Exchange Rate Volatility On US Exports: An Empirical Investigation", Southern Economic Journal, 62: 34-43.

Asseery, A, Peel, D.A (1991), "The Effects Of Exchange Rate Volatility On Exports: Some New Estimates", Economics Letters, 37: 73-177.

Baele, Lieven, Annalia Fernando, Peter Hordahl, Elizaveta Krylova, Cyril Monet (2004), "Measuring Financial Integration in The Euro Area", European Central Bank Occasional Paper Series No. 141 April 2004, European Central Bank.

Bahmani-Oskooee, Mozen, and Nabil Ltaifa (1992), "Effect Of Exchange Rate Risk On Export: Crosscountry Analysis", World Development, 20:1173-81

Bailey, M.J., G.S. Tavlas, Dan Ulan, M. (1987) "The Impact Of Exchange-Rate Volatility On Export Growth: Some Theoretical Considerations And Empirical Results” Journal Of Policy Modeling, 9: 225-243.

Barkoulas, John T., Christopher F. Baum, Dan Mustafa Caglayan (2002), "Exchange Rate Effects On The Volume And Variability Of Trade Flows", Working Paper, 1-27

Bayoumi, T. and B. Eichengreen (1998), "Exchange Rate Volatility and Intervention: Implications of the Theory of Optimum Currency Areas," Journal of International Economics 45, 191-209

Caporale, T. and Doroadian, K., 1994. Exchange rate variability and the flow of international trade. Economic letters. 46: 49-54.

Chowdhury, A. R. (1993), "Does Exchange Rate Volatility Depress Trade Flows? Evidence from Error-Correction Models", The Review of Economics and Statistics, 75(4), 700-706.

Côté, Agathe (1994), "Exchange Rate Volatility and Trade, a Survey", Bank of Canada Working Paper 94-5:1-31

Gagnon, JE (1993), "Exchange Rate Variability And The Level Of International Trade", Journal Of International 
Economics, 34: 269-87

Goeltom, Miranda dan Made Suardhini (1997), "Analisis Dampak Intervensi Bank Sentral Dalam Penetapan Nilai Tukar Terhadap Ekspor-Impor Indonesia", Ekonomi dan Keuangan Indonesia, Volume XLV, Nomor1

Hau, H. (2002), "Real Exchange Rate Volatility and Economic Openness: Theory and Evidence", Journal of Money, Credit and Banking, 34(3), 611-630

Hviding, Ketil, Michael Nowak, and Luca Antonio Ricci (2004), "Can Higher Reserves Help Reduce Exchange Rate Volatility?", IMF Working Paper WP/04/189, October.

Krugman Paul R, Maurice Obstfeld (2000), International Economic Theory and Policy, $5^{\text {th }}$ edition, Addison Wesley, Massachusetts

Pozo (1992), "Conditional Exchange Rate Volatility And The Volume Of International Trade: Evidence From The Early 1900s", The Review Of Economics And Statistics, 75: 325-329.

Rahutami, Ika dan Sri Yani Kusumastuti (2007), "Dampak Volatilitas Nilai Tukar Terhadap Arus Perdagangan Indonesia (Pendekatan ARDL-ECM)", Jurnal

Shin, Kwanho dan Yunjong Wang (2003), "Monetary Integration Ahead of Trade Integration in EastAsia”, Discussion Paper No. 572, The Institute of Social And Economic Research, Osaka University

Stokman, ACJ (1995) "Effect Of Exchange Rate Risk On Intra-EC Trade", De Economist, 143: 41-54

Susilo, Antonius (2001), "Dampak Ketidakpastian Nilai Tukar Indonesia tehadap Pertumbuhan Ekspor Periode 1979.1-1988.4 : Suatu Pendekatan Teknik Kointegrasi dan Model Koreksi Kesalahan", Thesis UI tidak dipublikasikan 